\title{
THE HYDROGRAPHICAL FEATURES OF THE WATERS OF PALK BAY DURING MARCH, 1963
}

\author{
By A. V. S. MURTY \& P. UDAYA VARMA \\ Central Marine Fisheries Research Sub-Station, Emakulam-6
}

\section{N T R O D U C T I O N}

DURING the 26th cruise of the Research Vessel VARUNA, the Palk Bay has been covered from 18th to 20th March, 1963. The location of the Stations (Nos. 1631 to 1681) occupied during this cruise are shown in Fig. 1.

The Bay is a very shallow and flat basin, nowhere exceeding 15 metres deep. On an average its depth hardly exceeds 9 metres. Temperature, salinity and dissolved oxygen are the parameters of which the data have been collected during the cruise. Samples were taken from the surface at every station and from 5 metre depth at many stations and also from 10 metre depth at a few stations depended on the sonic depth of the station. These data have been used for bringing out the hydrographic features of the Palk Bay. The prevailing winds are also considering in the analysis, the relevant wind date being taken from the daily weather reports of the Indian Mateorological Department. The Palk Bay is divided into four different zones based on the nature of the data collected and the distributions of different parameters in these four zones are also presented.

\section{DISTRIBUTION OF SURFACE TEMPERATURE}

The surface waters are subjected to diurnal variations of temperature due to the heating by day and cooling by night. The variations are much more appreciable in case of shallow basins due to the less thermal capacity of the basin waters. It will be possible to compare the temperatures over different regions, only when the diurnal variations of temperature are minimised so that they can be neglected. Since the data of the Palk Bay are collected for three days, it is necessary to eliminate or minimise the diurnal variations from the observed surface temperatures. This may be achieved from shore-station observations. The observations at a shore station near Waltair $\left(17^{\circ} 41^{\prime} \mathrm{N}, 83^{\circ} 17^{\prime} \mathrm{E}\right)$ on the diurnal variations of surface temperature, connect the amplitude of temperature with hour of observation for the month of March 1960. The amplitude of temperature of (in ${ }^{\circ} \mathrm{C}$ ) about the daily mean temperature is given by

$$
\begin{gathered}
,\left(=-0.58 \operatorname{Cos} \sim_{2} 1+0.15 \operatorname{Cos} \wedge t-0.02 \operatorname{Cos}-? \mathrm{~J} /-0.72 \operatorname{Sin}-\wedge /\right. \\
-0.10 \mathrm{Sin} \wedge^{\wedge} \mathrm{J} / .0 .07 \operatorname{Sin} \sim-1,
\end{gathered}
$$

where / is measured in hours starting from midnight (Ramanadham and Murtyunpublished). The corrections for diurnal variation $\left(-\mathrm{o}^{\circ} \mathrm{C}\right)$ have been applied for the observed temperatures of the surface waters of the Palk Bay. 
The distribution of temperature of the surface, after being corrected for daily variations, is shown in Fig. 2. Temperature is less in the southern region as com-

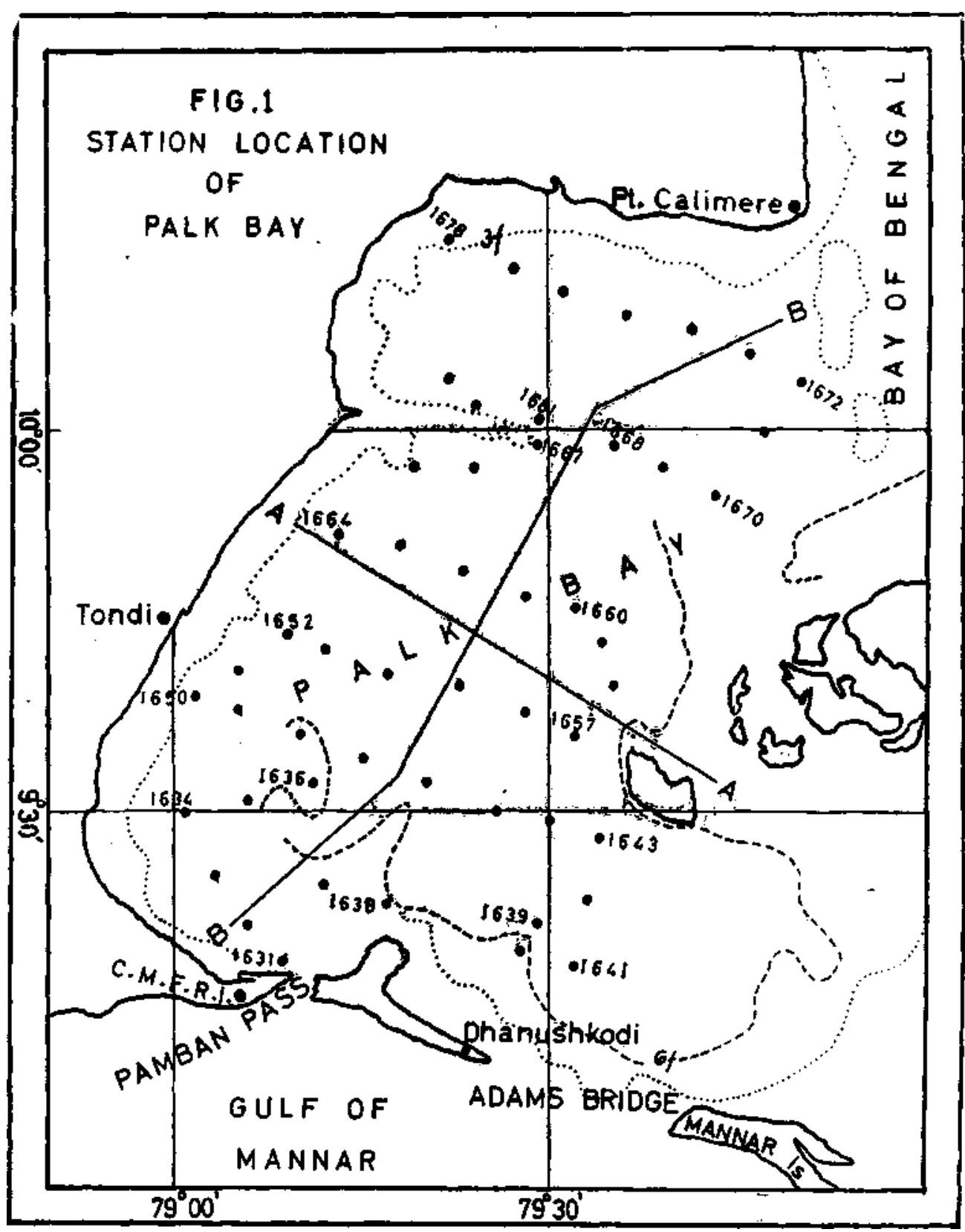

pared to the coastal region of the west and north-west of the Bay. They are moderate in the neighbourhood of the Palk Strait (north eastern region of the Bay). 
The moderately cool water of the Bay of Bengal after entering the Palk Strait extends its influence almost to the middle of the west coast and in doing so, it divides the coastal waters of relatively high temperature into two separate cells. The temperatures of the region west of Pamban Pass are comparable with those of the

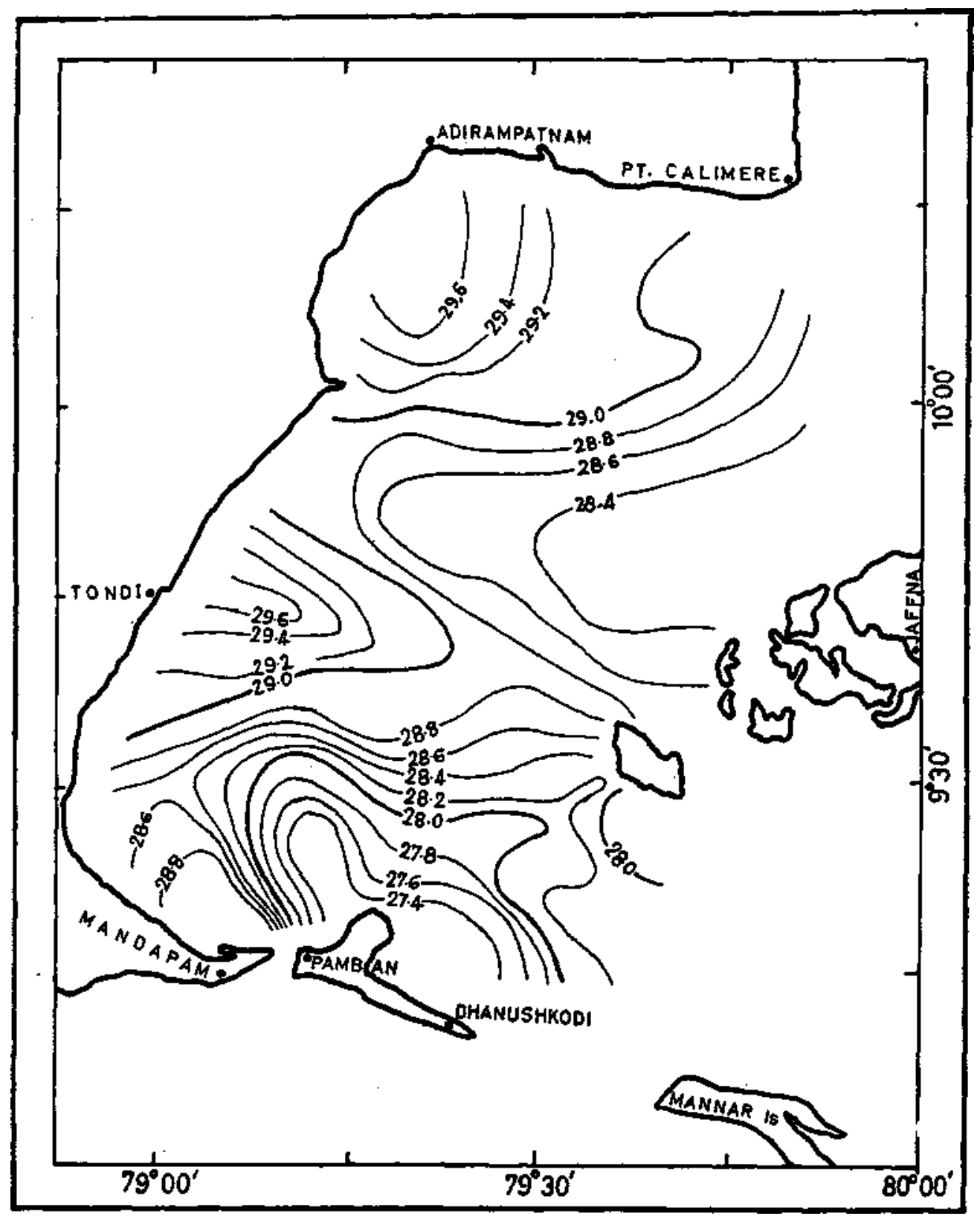

Fig. 2. Distribution of surface temperature $\left({ }^{\circ} \mathrm{C}\right)$ in Palk Bay during March, 1963. 
Strait. The thermal gradients are low in the northern region but they are high in the south. There is a very high positive gradient of temperature from the Rameswaram Island (Pamban) to Tondi.

\section{DISTRIBUTION OF SURFACE SALINITY}

The distribution of surface salinity is illustrated in Fig. 3. The salinity value depends not only upon the origin of watermass but also on the evaporation from the surface. Unless the factors of evaporation, such as the winds and humidity gradients in the microlayers of air over the surface are known, the effect of evaporation on local salinity values cannot be discussed. Nevertheless, 'the salinity variations are further complicated by mixing of watermasses brought into effect by currents and turbulent exchanges.

The $32 \%$, isohaline serves as a line of demarcation between the low saline coastal waters to its left and high saline Bay of Bengal waters to its right. The incursion of the Bay of Bengal water into the Palk Bay through the Strait is such that it splits the coastal water into-two separate cells. Except for a weak trough (31\% isohaline) at the centre of the Bay, the salinity decreases gradually along an axis in the south-west direction running from tne Strait. Highly saline water is pocketed in the south-southwestern corner of the Bay. This may be due to the incursion of the Gulf water through the Pamban Pass. The circulation in the south-western region may be weak and the coastal configuration may be hydrodynamically protective constituting the causes for the entrapment of the high saline Gulf water without being mixed with the low saline coastal water in the south. Water having a salinity less than $30^{\wedge}$ o may be treated as coastal water. The coastal water in the north is confined to a narrow region near the coast, whereas in the south the coastal water extends even to the middle of the Bay. The west-southwestern region is having the lowest saline water.

Along an axis in the direction of south-west from the Strait the salinity at first decreases gradually and then more rapidly towards the further end of this axis, disregarding the shallow dip at the middle. The gradient is very strong in the southwest, as in the case of temperature.

\section{DISTRIBUTION OF SURFACE DENSITY $(a-$, $)$}

The values of surface density $(<\mathrm{r}$,) have been computed by making use of the data presented in Figs. $2 \& 3$. The density distribution of the surface of the Palk Bay is illustrated in Fig. 4. The isopycnal of the value $a_{t}=20$ in the north may be treated as a forward boundary of the Bay of Bengal water. Similarly, the isopycnal $a_{-t}=19$ may be the limiting contour for coastal water. As in the case of salinity, it is also clear from the orientation of the isopycnal $a-=19$ that the coastal water is limited to a narrow region in the north-west and to a wider area in the south-west. It is also clear that the Gulf water near the Pamban Pass in the south is locked under the protective configuration of the coast.

The sharp gradients of density of the south-western region indicate that mixing of the coastal water with the sea (Gulf) water is not prominent in this region. It can be further inferred from the orientation of the isopycnal $0-/=20$ that the influence of the Bay of Bengal water on the Palk Bay is much more extensive and 


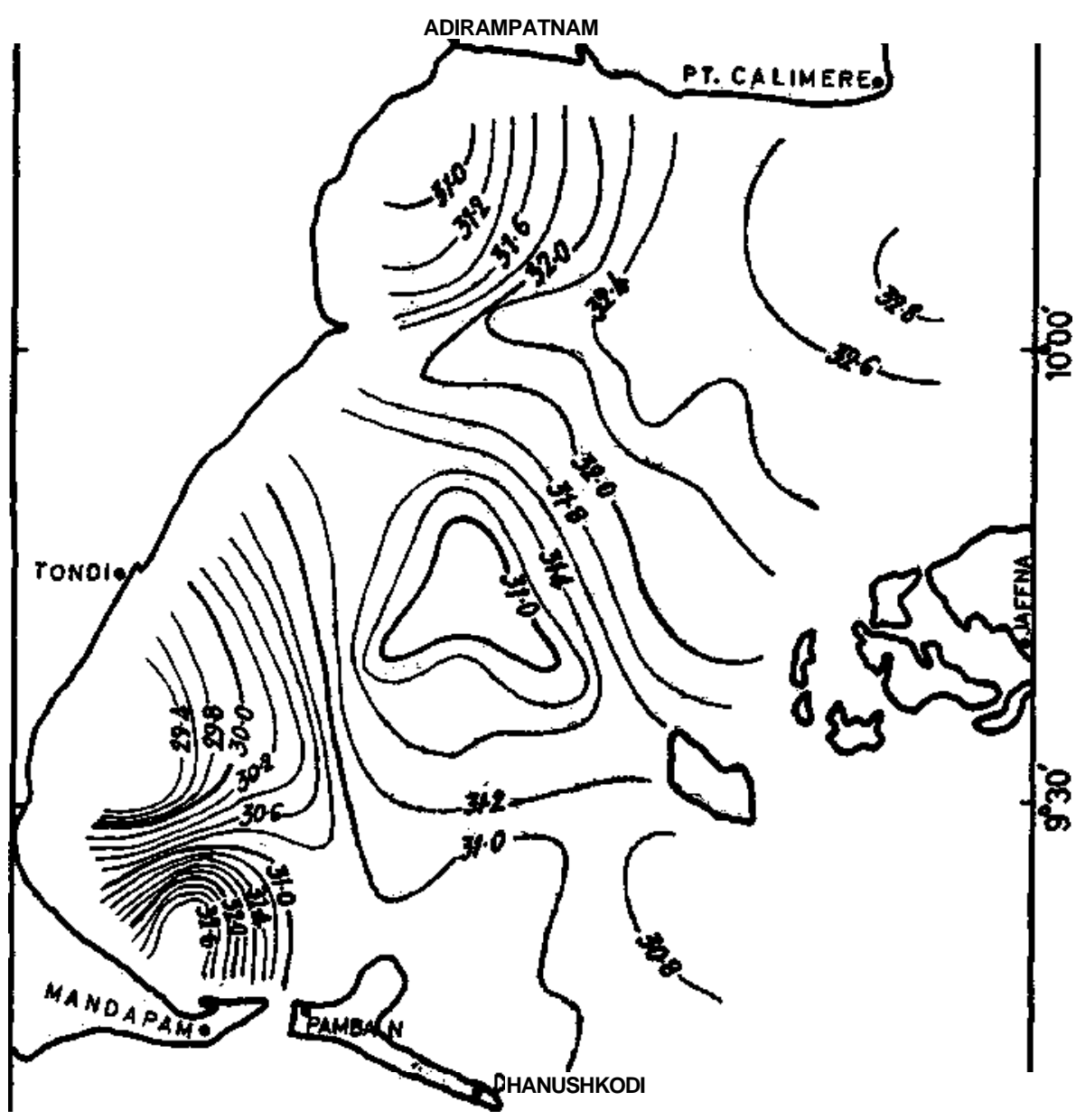

\section{$<\mathfrak{e f c v}$}

$79^{\circ} 00^{\prime}$

$79^{\circ} 30^{\prime}$

8fJ00'

Fig. 3. Distribution of surface salinity $\left(\%_{0}\right)$ in Palk Bay during March, 1963.

intensive than the Gulf waters. The density decreases along an axis in the southwestern direction from the Strait, the waters being more of sea origin at the beginning and more of coastal origin towards its further end. 
The distribution of dissolved oxygen $(\mathrm{ml} / 1)$ in the surface waters of the Palk Bay is shown in Fig. 5. This being a shallow body of water, the effect of wind

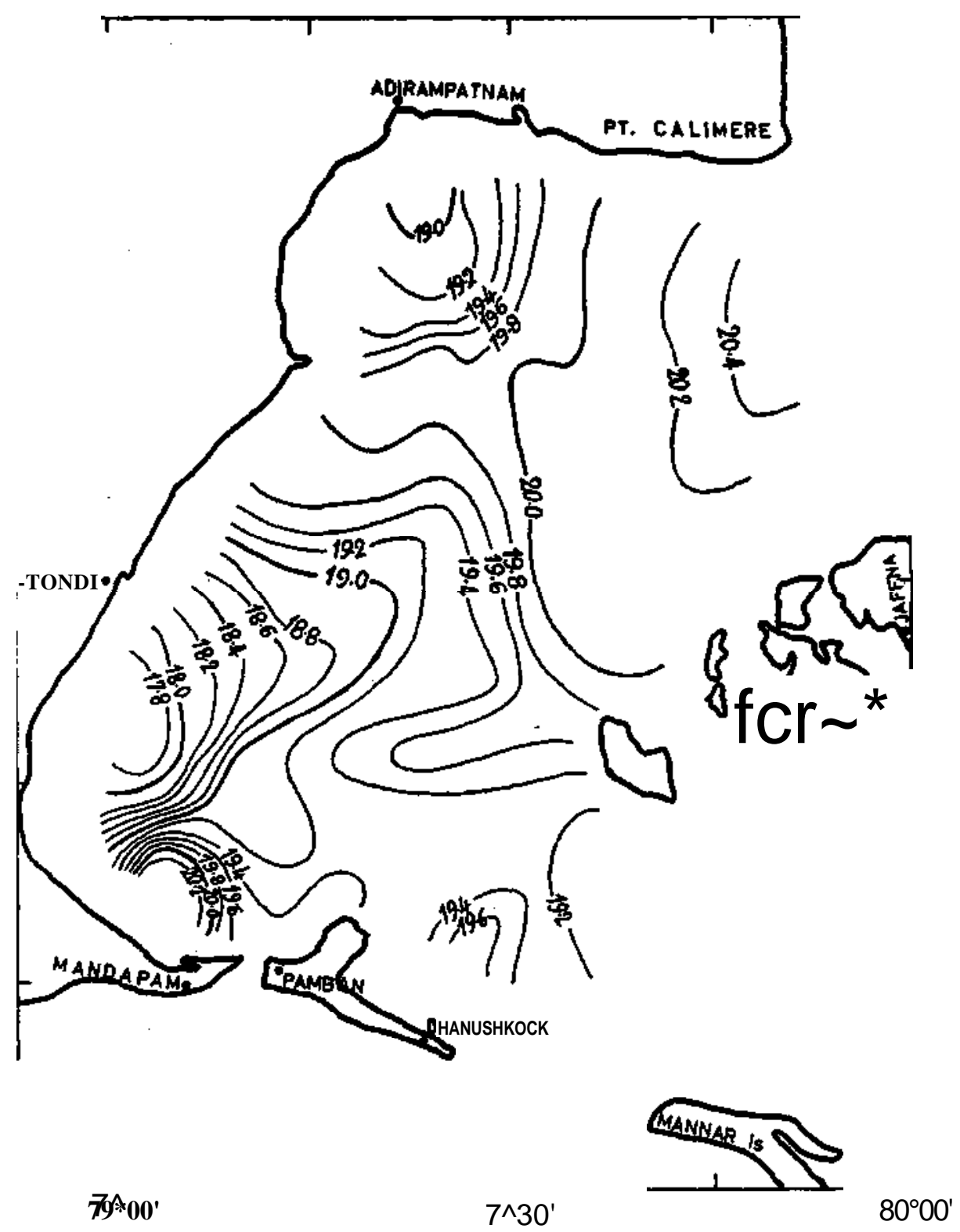

Fig. 4. Distribution of surface density (at) in Palk Bay during March, 1963. 
mixing, apart from the biochemical factors, in the horizontal and vertical distribution of oxygen is suspected. Hence the speed and direction of the wind over the Bay were computed from the daily Weather Reports of the shore stations of Nagapattinam and Pamban obtained from the Indian Meteorological Department. These

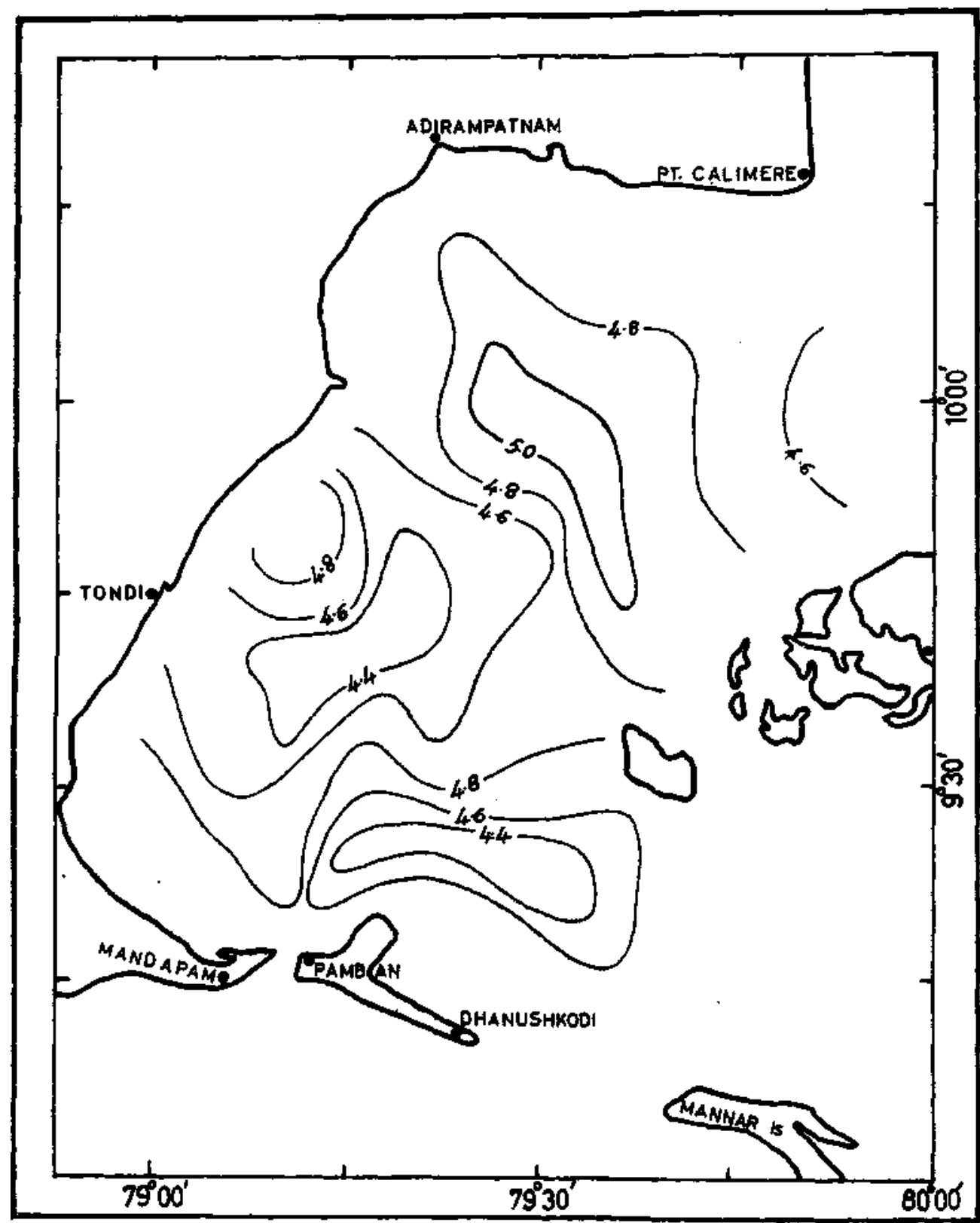

Fig. 5. Distribution of surface diswlved oxygen <ml/I) in Palk Bay during March, 1963 
computations show that the North-East winds are more frequent during this period. The wind strength at Nagapattinam is about 8 to 10 knots on an average for the month, and at Pamban it is only 2 to 4 knots. It means that the wind blows over the Palk Bay in the same direction over the northern and the southern region, but with different strength. The winds over the Palk Strait are considerably strong and they decrease along the axis in the south-western direction to attain a minimum speed at the lower end of the axis.

The oxygen content in the surface waters at the Strait is less when compared to that of the waters a little further inside the Palk Bay, in spite of the strong winds at the former region. In the open sea (the Bay of Bengal) the surface oxygen is distributed over a considerable length of water column in the vertical. On the contrary, only a very short column of water shares the oxygen from the surface a little left of the Strait since the depth is hardly 5 fathoms. Therefore, the oxygen content is slightly higher towards left of Palk Strait though the winds are stronger towards its right. As the winds are weakened along the axis of the Bay in the south-western direction, so is the distribution of oxygen content in this direction.

It is noteworthy that the waters everywhere in the Palk Bay are almost saturated with dissolved oxygen. They sometimes even exceed the saturation limit by a small percentage, especially in the northern region.

\section{ZONAL DISTRIBUTION OF PHYSICAL AND CHEMICAL PROPERTIES}

In view of the nature of observations, the Palk Bay is divided into four different zones by the lines $\mathrm{AA}$ and $\mathrm{BB}$ as shown in Fig. 1. The division is such that each zone contains the data partly covered by night and partly by day. The diurnal changes, within certain limitations, can therefore be expected to affect all the four zones in a similar way.

The distribution of the physical and chemical properties are represented in the Table for all these zones. The Table gives a summary of the regional differences of properties of the Bay waters. It differentiates the warm, low saline and low oxygen and light waters of the south-western zone from the moderately cool but highly saline and rich oxygen and denser sea waters of the diagonally opposite north-eastern zone.

At least some of the properties are similar for all the four zones. With all that, the south-western zone remains distinctly separate from the rest of the four zones.

\section{SUMMARY}

The Palk Bay is a shallow and flat basin, the depth of which being on an average 9 metres and nowhere exceeding 15 metres. The hydrography and dissolved oxygen conditions of the Bay waters are studied during the month of March 1963.

The distributions of temperature, salinity, density and dissolved oxygen of the surface waters of the Palk Bay indicate that the Bay of Bengal waters entering through the Palk Strait have major influence on the hydrographic conditions of the Palk Bay. The Gulf waters influence the Palk Bay to a minor extent only. 
TABLE

Zonal Distribution of Physico-Chemical Properties of the Palk Bay

\begin{tabular}{|c|c|c|c|c|c|c|c|c|c|c|c|c|c|c|}
\hline \multirow{2}{*}{ Zone } & \multicolumn{2}{|c|}{$\begin{array}{l}\text { Surface } \\
\text { Temperature } \\
{ }^{\circ} \mathbf{C}\end{array}$} & \multicolumn{2}{|c|}{ Temperature } & \multicolumn{3}{|c|}{$\begin{array}{l}\text { Salinity } \\
\quad / 00\end{array}$} & \multirow{2}{*}{$\begin{array}{c}\text { Surface } \\
\text { Density } \\
\quad \text { at } \\
\\
\\
\ll)\end{array}$} & \multicolumn{3}{|c|}{$\begin{array}{l}\text { Dissolved } \\
\text { Oxygen } \\
\text { ml/1 }\end{array}$} & \multicolumn{3}{|c|}{$\begin{array}{c}\text { Percentage saturation } \\
\text { of } \\
\text { Dissolved Oxygen }\end{array}$} \\
\hline & $\begin{array}{l}\text { Corrected } \\
\text { for daily } \\
\text { variations }\end{array}$ & 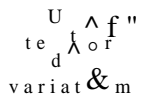 & $5 \mathrm{~m}$. & $10 \mathrm{~m}$. & Surface & $5 \mathrm{~m}$. & $10 \mathrm{~m}$. & & Surface & $5 \mathrm{~m}$. & $10 \mathrm{~m}$. & Surface & $5 \mathrm{~m}$. & $10 \mathrm{~m}$. \\
\hline North-West & 29.1 & 29.0 & 28.8 & .. & 31.85 & 31.86 & .. & 19.71 & 4.7 & 4.7 & & 106 & 105 & \\
\hline North-East & 28.6 & 28.8 & 28.7 &.. & 32.29 & 32.24 & , & 20.19 & 4.7 & 4.6 & & 106 & 103 & \\
\hline South-East & 28.4 & 28.5 & 28.7 & 28.4 & 31.10 & 31.02 & 31.23 & 19.50 & 4.6 & 4.8 & 4.6 & 102 & 105 & 102 \\
\hline South-West & 29.0 & 28.6 & 28.6 & & 30.26 & 30.24 & & 18.70 & 4.6 & 4.5 & & 100 & 100 & \\
\hline
\end{tabular}


Winds blow over the Palk Bay from the north-east. They are strong at the Palk Strait and weak towards the south-western end of the Bay.

The dissolved oxygen reaches nearly its saturation value over the entire Bay. Sometimes it exceeds its saturation limit by a small percentage. The general pattern of distribution of dissolved oxygen of the surface layers is in accordance with the wind conditions over the Bay.

The waters adjacent to the coast have high temperature, low salinity and low density* The Bay of Bengal water extends its influence almost to the middle of the coast and hence separates the coastal water into two cells.

Denser sea water is pocketed near the coast at the south-western region of the flay. The south-western zone is the least disturbed area under the protective configuration of the coast and the non-disturbing atmosphere. The coastline of the north-western region is similarly protective. But the waters in this region are disturbed by the strong north-easterly winds and the associated circulation of water through the Strait. 